\title{
Safety evaluation of power supply system for Urban Rail Transit Yang $\mathrm{Li}^{1}$, a, Yiru Cui ${ }^{1, b}$ \\ 1School of Traffic and Transportation, Beijing Jiaotong University, Beijing 100044, China a16120954@bjtu.edu.cn, b16120790@bjtu.edu.cn
}

Keywords: Rail transit. Power supply system. Safety evaluation.

Abstract. In order to prevent the occurrence of all kinds of safety accidents in urban rail transit project, the safety evaluation work is paid more and more attention. Safety evaluation work is a powerful guarantee for urban rail transit construction and operation safety. In this paper, AHP and comprehensive evaluation method are used to evaluate the safety of urban rail transit power supply system, and establish the corresponding index system, and get the method of safety evaluation.

\section{Introduction}

City rail transit system to ease city traffic congestion, has important social significance and economic significance of saving energy, to ensure system security and to improve transport capacity, city rail traffic in each line of the design development stage will need to do safety analysis and evaluation, and makes the system comply with the safety requirements throughout the life cycle.

Power supply system is the basic system of urban rail transit. The component is composed of many facilities and equipment, so the reliability, security and availability of the system have great influence on the whole system. [1] The establishment of safety evaluation system of urban rail transit power supply system is conducive to better protect the lives and property of the country and the people, reduce the occurrence of casualties, ensure social stability and promote economic development. The establishment of power supply system of city rail traffic safety evaluation system for the safety degree of each stage of rail transit projects for comprehensive evaluation, objectively reflect the city track traffic engineering safety situation in the process of construction and operation, to take timely corrective measures to ensure safe operation. [2]

\section{Research Content}

Introduction of Power Supply System. Power supply system [3] can be divided into three modes: centralized power supply, decentralized power supply and hybrid power supply. At present, China's new and under construction of urban rail transit projects, mainly the use of centralized power supply mode. Therefore, the evaluation of the power system is mainly in accordance with the idea of centralized power supply, the other two power supply mode can refer to centralized power supply.

The power supply system of city rail transit[4] mainly consists of the following parts: the main substation (for centralized power supply), ring cable, traction / step-down substation, traction power network, power station and tunnel lighting distribution system, SCADA system, stray current protection system, lightning protection and earthing system etc.. As shown in Fig.1: 


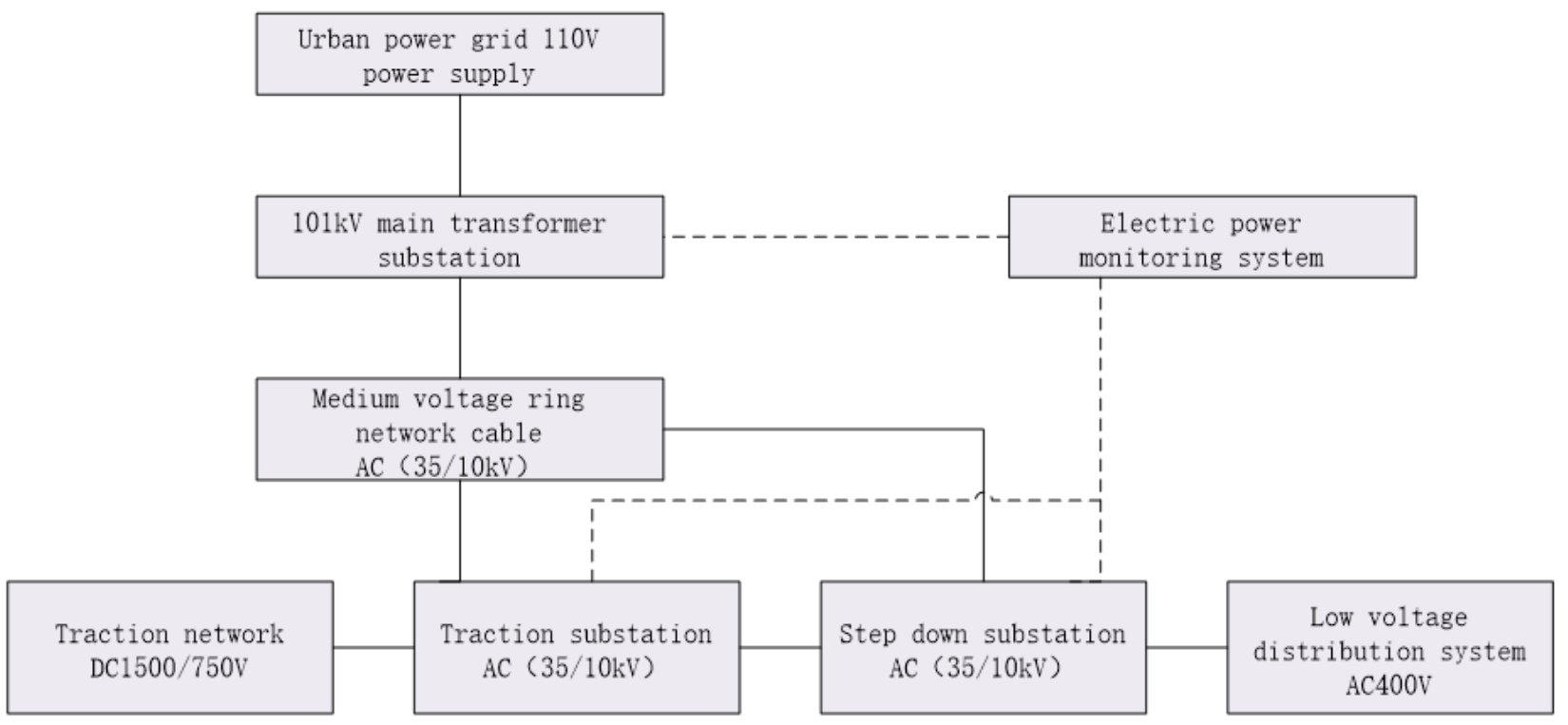

Fig. 1. Centralized Power Supply Mode

Safety Evaluation Index System of Power Supply System. This article uses AHP and comprehensive evaluation method for safety assessment, the operation mode of the system is analyzed, in the evaluation when the first to clarify the relationship between levels of each system, make scientific and representative index evaluation.

Main Transformer Substation System. The main substation power system will make the direct power supply of the main substation system is part of the loss of power, the lower system also lost power, which led to the train station and lost power, lighting, ventilation and running effect of the train station and a series of system, thus affecting the entire rail transit operation. [5] The maximum score of the main substation system is 34 . In the evaluation of equipment and facilities in the main substation system, only the equipment of the main substation system is considered. The maximum score of each index is shown in the Tab.1.

Table 1. Main transformer substation system score

\begin{tabular}{|c|c|c|c|}
\hline $\begin{array}{l}\text { First order } \\
\quad \text { index }\end{array}$ & $\begin{array}{l}\text { Secondary } \\
\text { indicators }\end{array}$ & Content evaluation & Score \\
\hline \multirow[b]{2}{*}{$\begin{array}{c}\text { Main } \\
\text { transformer } \\
\text { substation } \\
\text { system }\end{array}$} & $\begin{array}{l}\text { Safety, } \\
\text { reliability and } \\
\text { availability } \\
\text { index }\end{array}$ & $\begin{array}{l}\text { Maintenance qualification rate } \\
\text { Equipment failure rate } \\
\text { System load intensity } \\
\text { System failure time (105 min / year) }\end{array}$ & $\begin{array}{l}5 \\
7 \\
5 \\
7\end{array}$ \\
\hline & $\begin{array}{c}\text { Main substation } \\
\text { safety } \\
\text { protection } \\
\text { facilities }\end{array}$ & $\begin{array}{l}\text { Whether the building is equipped with lightning } \\
\text { protection facilities } \\
\text { Whether to set up perfect overload and short circuit } \\
\text { protection device } \\
\text { Whether to set up the fire alarm device } \\
\text { Whether to set up emergency lighting } \\
\text { Whether to set up safety warning signs and safety } \\
\text { evacuation instructions }\end{array}$ & $\begin{array}{l}2 \\
2 \\
2 \\
2\end{array}$ \\
\hline
\end{tabular}

Traction Substation System. Traction substation in the event of power failure, will cause the three-track loss of pressure, the subway train lost power and can not run normally, followed by many passengers stranded in the car. [6] Resulting in operational accidents. Traction substation system maximum score of 26 points. The maximum score of each index is as Tab.2: 
Table 2. Traction substation system score

\begin{tabular}{|c|c|c|c|}
\hline $\begin{array}{l}\text { First order } \\
\quad \text { index }\end{array}$ & $\begin{array}{l}\text { Secondary } \\
\text { indicators }\end{array}$ & Content evaluation & Score \\
\hline \multirow{11}{*}{$\begin{array}{l}\text { Traction } \\
\text { substation } \\
\text { system }\end{array}$} & \multirow{4}{*}{$\begin{array}{c}\text { Safety, } \\
\text { reliability and } \\
\text { availability } \\
\text { index }\end{array}$} & System failure time & 7 \\
\hline & & Maintenance qualification rate & 3 \\
\hline & & Equipment failure rate & 5 \\
\hline & & System load intensity & 4 \\
\hline & \multirow{7}{*}{$\begin{array}{l}\text { Traction } \\
\text { substation } \\
\text { protection } \\
\text { facilities }\end{array}$} & Whether to set ground protection & 1 \\
\hline & & $\begin{array}{l}\text { Whether the building is equipped with lightning } \\
\text { protection facilities }\end{array}$ & 1 \\
\hline & & $\begin{array}{l}\text { Whether to set up perfect overload and short circuit } \\
\text { protection device }\end{array}$ & 1 \\
\hline & & $\begin{array}{l}\text { Is there a protection against atmospheric over voltage and } \\
\text { over operation }\end{array}$ & 1 \\
\hline & & Whether to set up disaster prevention alarm device & 1 \\
\hline & & Whether to set up emergency lighting & 1 \\
\hline & & $\begin{array}{c}\text { Safety operation warning signs and safety evacuation } \\
\text { signs }\end{array}$ & 1 \\
\hline
\end{tabular}

Step Down Transformer System. Buck converter system is directly related to the passengers, once the power system lighting, will make the station ventilation, lighting, AFC power, communication signal system will not be able to operate properly. [7] It is more severe in the below ground station, passengers may be eager to leave the station in the event of a power failure accident, causing stampede accident. According to the weight, step-down substation system maximum score of 22 points, the maximum score of each indicator, such asTab.3:

Table 3. Blood pressure change system score

\begin{tabular}{|c|c|c|c|}
\hline $\begin{array}{l}\text { First order } \\
\text { index }\end{array}$ & $\begin{array}{l}\text { Secondary } \\
\text { indicators }\end{array}$ & Content evaluation & Score \\
\hline \multirow{14}{*}{$\begin{array}{c}\text { Step down } \\
\text { transformer } \\
\text { system }\end{array}$} & Voltage & System failure time & 5 \\
\hline & reducing & Maintenance qualification rate & 2 \\
\hline & transformer & Equipment failure rate & 3 \\
\hline & substation & Equipment repair rate & 2 \\
\hline & equipment & System load intensity & 3 \\
\hline & \multirow{9}{*}{$\begin{array}{c}\text { Safety } \\
\text { protection } \\
\text { facilities for } \\
\text { step-down } \\
\text { substation }\end{array}$} & Whether to set ground protection & 1 \\
\hline & & $\begin{array}{l}\text { Whether the two sets of power distribution transformers } \\
\text { are set up in the step-down substation }\end{array}$ & 1 \\
\hline & & Whether to set up perfect overload and short circuit relay & 1 \\
\hline & & $\begin{array}{l}\text { Is there a protection against atmospheric over voltage and } \\
\text { over operation }\end{array}$ & 0.5 \\
\hline & & Whether to set up disaster prevention alarm device & 1 \\
\hline & & Whether to set up emergency lighting & 0.5 \\
\hline & & $\begin{array}{c}\text { Whether or not the step-down substation is equipped with } \\
\text { monitoring facilities }\end{array}$ & 0.5 \\
\hline & & $\begin{array}{l}\text { The failure information and operation information of all } \\
\text { the equipment in the step-down substation }\end{array}$ & 0.5 \\
\hline & & $\begin{array}{c}\text { Whether or not to set up safety operation warning signs } \\
\text { and safety evacuation instructions }\end{array}$ & 1 \\
\hline
\end{tabular}


Power Cable and Power Monitoring System. The maximum score of power cable and electric power monitoring system is 18 , and the maximum score of each index is the following Tab.4:

Table 4. Rating of power cable and power monitoring system

\begin{tabular}{|c|c|c|c|}
\hline $\begin{array}{l}\text { First order } \\
\text { index }\end{array}$ & $\begin{array}{l}\text { Secondary } \\
\text { indicators }\end{array}$ & Content evaluation & Score \\
\hline \multirow{4}{*}{$\begin{array}{c}\text { Power } \\
\text { cable and } \\
\text { power } \\
\text { monitoring } \\
\text { system }\end{array}$} & $\begin{array}{l}\text { Power cable } \\
\text { setting }\end{array}$ & $\begin{array}{l}\text { Low smoke, halogen free flame retardant cable when } \\
\text { laying on the ground / underground. } \\
\text { Cable through the wall, the floor of the hole, whether } \\
\text { the implementation of fire blocking }\end{array}$ & 2 \\
\hline & Control center host & $\begin{array}{l}\text { The control center can monitor the substation and the } \\
\text { contact network in real time } \\
\text { After the failure of the transformer, the power } \\
\text { monitoring system can be switched } \\
\text { The problems of the substation equipment and the } \\
\text { position of the contact network can accurately display }\end{array}$ & 2 \\
\hline & $\begin{array}{l}\text { Remote control } \\
\text { terminal of each } \\
\text { substation }\end{array}$ & $\begin{array}{l}\text { The use of the terminal is in the service life } \\
\text { The sensitivity of the control terminal can meet the } \\
\text { monitoring needs }\end{array}$ & $\begin{array}{l}2 \\
3\end{array}$ \\
\hline & $\begin{array}{l}\text { Communication } \\
\text { network for } \\
\text { connecting } \\
\text { terminal and center }\end{array}$ & $\begin{array}{l}\text { To ensure the smooth exchange of information } \\
\text { between remote control terminal and control center }\end{array}$ & 3 \\
\hline
\end{tabular}

Scoring rules. Power supply system is very important to the safety of urban rail transit, which requires that the system has high reliability, security and availability. [8] In a comprehensive analysis of existing data and documents, the index is divided into four grades, and in accordance with the different levels, given different scoring rate, maximum score and then the score rate multiplied by the corresponding index, we calculated the actual score of each index. The table below is the score Tab.5:

Table 5. Scoring rate control table

\begin{tabular}{c|cccc}
\hline Safety index & $I$ & $I I$ & $I I I$ & $I V$ \\
\hline Equipment maintenance & $60 \% \geq \mathrm{M} \geq 40 \%$ & $80 \% \geq \mathrm{M}>60 \%$ & $90 \% \geq \mathrm{M}>80 \%$ & $\mathrm{M}>90 \%$ \\
qualification rate & & & & \\
Equipment failure rate & $\mathrm{M}>8 \%$ & $8 \% \geq \mathrm{M}>4 \%$ & $4 \% \geq \mathrm{M}>2 \%$ & $2 \% \geq \mathrm{M}$ \\
Equipment repair rate & $\mathrm{M}>15 \%$ & $15 \% \geq \mathrm{M}>10 \%$ & $10 \% \geq \mathrm{M}>5 \%$ & $5 \% \geq \mathrm{M}$ \\
Equipment load intensity & $\mathrm{M}>1.7$ & $1.7 \geq \mathrm{M}>1.3$ & $1.3 \geq \mathrm{M}>1$ & $1 \geq \mathrm{M}$ \\
Available time (min) & $\mathrm{M}>320$ & $320 \geq \mathrm{M}>210$ & $210 \geq \mathrm{M}>105$ & $105 \geq \mathrm{M}$ \\
Score rate & $20 \%$ & $55 \%$ & $80 \%$ & $100 \%$ \\
\hline
\end{tabular}

The formula for calculating the score of a given station power supply system:

$P_{n(s)}=p_{(m)}+p_{(t)}+p_{(r)}+p_{(b)}$

The meaning of the letters in the alphabet:

$P_{n(s)}:$ Score of power supply system;

$p_{(m)}$ : Monitoring system score;

$p_{(t)}$ : Main transformer substation system score;

$p_{(r)}:$ Traction substation system score; 
$p_{(b)}$ : Blood pressure and power system.

Classification of management risk levels. For the power supply system of urban rail transit, the level of risk must be controlled as Tab.6.

Table 6. Risk grade classification table

\begin{tabular}{c|ccccc}
\hline Security level & $I$ & $I I$ & $I I I$ & $I V$ & $V$ \\
\hline Comment & Security & More secure & Safety hazard & More dangerous & Danger \\
Safety score & $\mathrm{P} \geq 90$ & $90>\mathrm{P} \geq 80$ & $80>\mathrm{P} \geq 70$ & $70>\mathrm{P} \geq 60$ & $\mathrm{P}<60$ \\
\hline
\end{tabular}

\section{Conclusion}

In this paper, based on the principle of evaluation system, the evaluation system of urban rail transit power supply system is constructed. Combined with the existing literature, the content of evaluation index and index is given, and the risk grade and risk level of each system are classified by the analytic hierarchy process and the comprehensive evaluation method.

However, due to the lack of sufficient data to support the classification of risk levels, it is too broad, and the accuracy of the model of the evaluation system needs to be further improved.

\section{References}

[1] G.P. Xiao, X.N. Zhu, Traffic Safety Engineering [M]. Beijing: China Railway Press, 2016

[2] Y. Yue, Study on the Safety Evaluation of Railway Passenger Station [D]. Southwest Jiao Tong University, 2010

[3] B.H. Mao, X.M. Li, M.S. Wang, City Rail Transit Operation Management System [M]. Beijing: China Communications Press, 2006

[4] Y. Zhang, H.B. Zhang, Power Flow Analysis of Medium Voltage Network in Urban Rail Transit Power Supply System [J]. Research on Urban Rail Transit, 2010, 13 (8): 43-48.

[5] J. Qin, G.F. Gao, Safety Management of Urban Rail Transit [M]. Beijing: China Communications Press, 2011

[6] Z.Y. Yang, C.K. Huang, J.B. Qu, Bridge Safety Evaluation Fuzzy Comprehensive Evaluation and Analytic Hierarchy Process [J]. Journal of Tianjin University, based on the 2005, 38 (12): 1063-1067.

[7] L. Han, Q. Mei, Y.M Lu, etc., The Fuzzy Comprehensive Evaluation Method of AHP- Analysis and Research [J]. Chinese Safety Science Journal, 2004, 14 (7): 86-89.

[8] J.W. Tian, M.J. Gao, Research and Applications of Artificial Neural Networks [M]. Beijing Institute of Technology Press, 2006 